\title{
SOVEREIGNTY THIS CENTURY - MAORI AND THE COMMON LAW CONSTITUTION
}

\author{
Paul McHugh*
}

This paper is an attempt to give a panorama of constitutional life in New Zealand this century as viewed through a particularly important window, the status of the aboriginal Maori people of these islands. Questions of Maori rights and their position in the constitutional order have become burning issues in this final quarter century and represent an immense challenge for the next. This exploration is particularly appropriate as we celebrate a century of law teaching in this capital city at a University which has produced many if not most of this country's distinguished and influential public lawyers. In many respects, the history we are about to review is also a history of common law constitutionalism in this country as well to a lesser extent as similar Anglophonic jurisdictions. We are looking not just at how that part of the common law we call "public law" has dealt with a particular ethnic group. Through this aboriginal window we are looking at the changing logic and reach of public law through the past century and at the nature and character of the common law itself.

\section{INTRODUCTION}

The relationship between the Crown, as holding and embodying the power of the state, and its subjects has been the enduring preoccupation of common law constitutionalism. This fixation has been embodied in that single, highly problematic word "sovereignty". For common lawyers, sovereignty has been a powerful organising concept which has dominated the way in which they think about public power and the nature of authority. The century of relations between Crown and Maori has been conducted in the shadow of that concept and the accompanying preoccupation with the "who" question, that is, the location of ultimate political authority. So a major theme in this paper will be sovereignty as the axis of constitutional thought and practice in the common law.

* Tutor, Sidney Sussex College and Lecturer in Law, University of Cambridge. 
There are two closely linked processes going on as we common lawyers think and act upon our idea of the constitution. First, we are acting upon some sense of the constitution as a living body of doctrine and rules authorising certain conduct within the public sphere - the constitution as a set of available possibilities. But there is a second dimension to our common law method, one accentuated by the lack of an authoritative single constitutional instrument. This is the sense of the historic authorisation of the constitution. Common lawyers routinely and instinctively use the past to authorise the present. This trait is fundamental to common law method and supplies a vital element of common law constitutionalism, namely the sense of our constitution as an historically validated arrangement. Those two themes - of constitutional practice and historical authorisation of that practice - like that of sovereignty also have their own history. There is a history of constitutional practice and another history, an intellectual one, of the ways we have given that constitution historical validation (a history as it were of constitutional historiography). We will be dealing not just with themes - of sovereignty, constitutional practice and historiography - but with the history of those themes.

Societies exist in time and place and have their own depictions and memories of themselves as so existing. ${ }^{1}$ A constitution is, at least in western societies, a major expression of that activity - a fundamental means by which a society locates and authorises its organisation and presence in time and place. A constitution authorises and regulates political behaviour and where the polity lacks a single paramount and foundational document, then the sense of historical continuity will be a crucial source of constitutional authority. In today's world, a constitution authorises the power of the state, and part of that authorisation will involve invocation of the constitution's past as a means of legitimating or otherwise explaining its present arrangement. As well as carrying its own present and immediate authority, a constitution, especially an unwritten one, rests upon a shared sense of historical validation. Through that a polity is able to see itself as a continuous structure in time and place. As our constitutional arrangements spring from the common law, the concern here will be with the language of the common law both as a system of possibilities and as a way of remembering the past. It is those themes which I will discuss here - the constitution as a living and immediate thing as well as an historical artefact.

Let me start with an example.

1 J G A Pocock "Languages and their Implications: the Transformation of the Study of Political Thought" in J G A Pocock Politics, Language and Time Essays on Political Thought and History (University of Chicago Press, Chicago, 1971) 3. 
In the early seventeenth century when Englishmen described their relationship with an excessive Stuart monarch they used the common law. ${ }^{2}$ This common law was more than a body of rules describing their rights and liberties - it was a whole dominant way of thinking about political relationships in early Stuart England and was then the dominant (secular) language of political discourse. This language was not restricted in usage to a specialist clerisy centred around the Inns of Court and Westminster Hall, but was more widespread in its availability and practice. All educated Englishmen were versed in the language of the common law. This seventeenth century common law spoke of the ancient constitution of Englishmen, a constitution handed down from their ancient Gothic ancestors. These ancestors were conceived as living in a state of perfect, uncorrupted liberty in their forests and glens and it was this idealised state which Englishmen wished to have restored to them in seventeenth century England. At this time, Englishmen conceived of a constitutional order which was ancient, unwritten, enduring and historically undifferentiating, that is the rights this ancient constitution gave to their ancestors were identical to those demanded in the England of the early seventeenth century. Yet though that common law thinking refused to differentiate the ancient situation of Englishmen from their present (except in the present being one of deprivation), the rights they demanded were undoubtedly modern in character - jury trial and taxation only through Parliament, for example.

Ancient constitutionalism displayed two closely related features of common law method which have endured through several centuries. ${ }^{3}$ First, it demonstrated the constitution as having its own contemporaneity; that is to say, the constitution as a dynamic system living in and responding to its own turbulent and contingent present. The example I have given also reveals how at that time common lawyers had an historical memory of the constitution and recourse to this memory was itself an important part of the politics of the constitution. As ancient constitutionalism showed, this historical memory was very much apt to be affected by the requirements of the present. Common lawyers
have
always
had
a
present-

2 The classic text is JGA Pocock The Ancient Constitution and the Feudal Law: A Study in English Historical Thought in the Seventeenth Century (Cambridge University Press, Cambridge, 1957). Also Glenn Burgess The Politics of the Ancient Constitution: An Introduction to English Political Thought, 1603-42 (Macmillan Press, London, 1992).

3 For instance the essays in E Sandoz (ed) The Roots of Liberty: Magna Carta, Ancient Constitution and the Anglo-American Tradition of Rule of Law (University of Missouri Press, Columbia, 1993). In the context of Treaty claims in New Zealand, see R Boast "Lawyers, Historians, Ethics and the Judicial Process" (1998) 28 VUWLR 87. 
minded conception of the past, ${ }^{4}$ for that is central to their method. We do not study the past for its own sake but to establish authority within our own present. We imbue legal principle with a timelessness which allows us, if our own internal logic requires, to give a case from, say, 1794 as much imperative as one from 1994. Thus, when the New Zealand Court of Appeal speaks of "Treaty principles" and uses concepts like partnership, fiduciary-like duties and obligations of good faith it is not reading the Treaty of Waitangi as an historical document. Rather it is engaged in a public and somewhat controversial though utterly typical form of common law reasoning which is using the past to resolve contemporary problems. ${ }^{5}$

In the past 20 years, claims by aboriginal peoples in the courts and broader canvas of political life have made us as common lawyers more aware of its method as well as its doctrine. In the context of aboriginal peoples we realise that common law method and doctrine has been applied to a community outside its history and cultural thrall. This application to aboriginal peoples is as much as anything else the realpolitik of their colonised condition. But as common lawyers we can be self-aware within that situation, acknowledging the weaknesses as well as strengths of what is a robust vibrant human tradition. The greatest achievement of Anglophonic political culture, Sir Matthew Hale's seventeenth century metaphor is appropriately applied to us as tangata waka ${ }^{6}$, for we are all people of the canoes. The common law has been like the Argonaut's ship, which has Collected Papers of Frederic William Maitland (Cambridge University Press, Cambridge, 1911) Vol I, 491: "Thus we are tempted to mix up two different logics: the logic of authority, and the logic of evidence ... What the lawyers want is authority; ... what the historian wants is evidence ... This when stated is obvious; but we often conceal it from ourselves under some phrase about the common law." Also W Murphy "The Oldest Social Science? The Epistemic Properties of the Common Law Tradition" (1991) 54 MLR 182, 200; M Oakeshott "The Activity of Being an Historian" in M Oakeshott Rationalism in Politics and Other Essays (Pluto Press, London, 1962) 137; P Goodrich and Y Hachamovitch "Time out of Mind: An Introduction to the Semiotics of Common Law" in P Fitzpatrick (ed) Dangerous Supplements: Resistance and Renewal in Jurisprudence (Pluto Press, London, 1991) 159. 28 VUWLR 87.

This phrase has been used by Professor JGA Pocock to suggest an historiography of coexistence between Maori and Pakeha: "peoples of the ship, who have ocean voyages and the discovery of islands in their memory, their language and their history" in Professor J G A Pocock "Law, Sovereignty and History in a Divided Culture: The Case of New Zealand and the Treaty of Waitangi" (1998) 43 McGill Law J 481, 501 ["Law, Sovereignty and History"]. 
journeyed around the world carrying its scars and patches, its makeshift planks, hull and mast, not each the same that set out yet demonstrably still the same vessel. ${ }^{7}$

The intention here is to review a century of constitutional thought and practice in New Zealand through these two closely related themes of a constitution which is both set in a politicised present and which is also put into a past politicised by the present. Specifically, I will use the position of the aboriginal Maori people of New Zealand as a window to the experience of common law constitutional life on these islands. I hope that it will become plain that the themes I will touch upon apply more broadly to other contexts of New Zealand public life this century. The changing conceptions of judicial review are an example. Also, since we are dealing with the common law tradition I will make some observations about other Anglophonic common law jurisdictions. I am about to talk of three phases in the legal and constitutional position of Maori through the past century. These phases are also observable in North America and, to a fainter extent, Australia. ${ }^{8}$

The three phases which I am about to identify are not to be thought of as self-contained and rigidly separate. Rather they are three moods or climates - a kind of collective (sub-) consciousness which sustained enough in practice and thought and became in their time the predominant outlook. These are not water-tight periods so much as prevailing moods and positions, a "tradition" of that time.

Specifically, the constitutional phases through which relations with Maori have passed this century are these:

First, the longest phase with which this century began and which continued for nearly 70 years. This period may be called the Age of Leviathan, a reference to Thomas Hobbes' conception of an absolute sovereign with limitless and indivisible authority. In this period the New Zealand constitution took a sovereign-centred view of itself and its own history. It was, to use another person's phrase, the high period of the "Empire of Uniformity".9

The second phase may be described as "claims-time" - the period during the late 1970s and through the 1980s when Maori claims were heard and mechanisms set in place to address them. This phase coincided with a period in which the general principles of public

Sir Matthew Hale The History of the Common Law of England (published posthumously, reprinted 1713, 1716 and 1739); CM Gray (ed) The History of the Common Law of England by Sir Matthew Hale (University of Chicago Press, Chicago, 1971) 40.

8 Other writers have attempted to identify phases in Crown-aboriginal relations often in a comparative context. See Paul Havemann, editorial introduction, Indigenous Peoples' Rights in Australia, Canada and New Zealand (Oxford University Press, Auckland, 1999) 22-23.

9 James Tully Strange Multiplicity: Constitutionalism in an Age of Diversity (Cambridge University Press, Cambridge, 1995) 83. 
law concerning the justiciability of the exercise of power by state officials were broadening. Aboriginal claims - and the extension and incipient sophistication of judge-made doctrine during this period - should be seen in the context of these other developments in the public sphere of the common law; a particular manifestation of the common law's growing concern about the reach of the state and the position of the individual.

The third phase, where somewhat bumpily and unsettledly we are today, might be called "settlement-time". In New Zealand today the Crown is negotiating and concluding large settlements with Maori and this has produced a raft of constitutional and legal issues quite distinct to those which arose in claims-time. A similar jurisprudence of settlement is also emerging in Canada. It will be suggested that some of the legal and constitutional issues which this new political environment has generated are part of wider questions about the new role and ambit of public law in a context of dispersing (which is to say, less centralised) state power.

In each of those three phases one can discern distinct conceptions about the range of constitutional possibilities relating to Maori - what could be done in that particular legal present. There were also distinct ways of conceiving the constitutional past - how that particular present was then using its past.

\section{THE AGE OF LEVIATHAN}

The late nineteenth and much of the present century has been the great age of state nationalism, of the western conception of states as absolute sovereign beings. In this international setting, Britain and the Anglophonic states sharing the common law orbit (most as satellites of Westminster) moved, during the nineteenth century, towards a view of state sovereignty which might be described as Hobbesian. This adjective has been taken from Thomas Hobbes' Leviathan, a famous seventeenth century tract which became influential with the nineteenth century legal positivists ${ }^{10}$ and wherein the power of the sovereign Leviathan is described as absolute in being indivisible, unaccountable and unlimitable. It is this Hobbesian depiction which has gripped New Zealand's constitutional imagination for most of this century, as indeed most Anglophonic common law jurisdictions.

By the early nineteenth century the basic principle of the supremacy of the Crown in Parliament had long been established - that, after all, was what the Glorious and French Revolutions had been all about. However, during this period the English began to take a more conscious (and at times precious) attitude towards sovereignty as the central element of constitutional thought. Since at least the early seventeenth century, English political 
history had been a tussle over the location of the sovereign (that is, paramount political) power. Even after that was settled finally in 1745, there remained another century and a half of momentum in the issue: not until the end of the nineteenth century do we find the result of 1745 inscribed monumentally into the public sphere.

Before attempting a general explanation of that result, we can see the growing concern during the early nineteenth century with sovereignty as a doctrine by looking, for example, at imperial practice. The Six Nations of the Great Lakes region were the "allies" of the Crown after the Treaty of Paris 1763, but by the early 1830s they had mysteriously transformed into subjects of the Crown, ${ }^{11}$ at what moment or by what means no one has ever been able to explain. So too the inhabitants of the Mofussil, the Mughal provinces of Bengal, Bihar and Orissa, over which the East India Company obtained in 1765 a grant of diwani $^{12}$ (certain jurisdictional capacities derived from the Mughal). ${ }^{13}$ By the 1820 s these inhabitants were also the subjects of the Crown, ${ }^{14}$ the transformation in their relationship with the Crown again a matter of mystery. By the 1820s, imperial and colonial officials and judges ${ }^{15}$ were showing a much keener awareness of the nature of their sovereign rights over territory. The Treaty of Waitangi and similar treaties of cession in West Africa during the mid-nineteenth century ${ }^{16}$ are symptomatic of this sharper awareness of the nature of sovereignty and the growing insistence upon precision in the acquisition. ${ }^{17}$

This sharpening perception during the early nineteenth century of "sovereignty" was exposing the Hobbesian doctrine long implicit in British constitutionalism, although not packaged into a doctrinal bundle, and which, by the 1850s was set into imperial practice:

This was the position taken most notably by John Beverly Robinson, Attorney-General and later Chief Justice of Upper Canada: Robinson A-G to Boulton S-G, 31 October 1829, NA RG 10, Vol 5: fol 2290-91; Sheldon v Ramsay (1852) 9 UCQB 105, 134 per Robinson CJ.

12 Text in 43 Consolidated Treaty Series 217.

13 MP Jain Outlines of Indian Legal History (2 ed, NM Tripathi, Bombay, 1966) 82-84.

14 The Charter Act 1813, 53 Geo III, c 155 declared for the first time the undoubted sovereignty of the Crown. The Act was taken as declaratory: Mayor of the City of Lyons $v$ East India Co (1836) 1 Moo PC 175, 18 ER 66.

15 For example Freeman v Fairlie (1828) 1 Moo Ind App 305; 18 ER 117 (Ch).

16 For instance the Ceded Mile Treaty with King Burungai Sonko of Barra (1826) (text in 78 Consolidated Treaty Series 281) and see the account in JM Gray A History of the Gambia (Cambridge University Press, Cambridge, 1940) 341. The tempo of British treaty-making in West Africa increased dramatically from the mid-1820s: see E Hertslet The Map of Africa by Treaty (2 ed, London, 1896).

17 Also E Hertslet "Memorandum on Formalities Necessary for Effective Annexation" 18 October 1884 in FO84/1813:246-65; WE Hall A Treatise on the Foreign Powers and Jurisdiction of the British Crown (Clarendon Press, Oxford, 1894). 
sovereignty as absolute, territorial, indivisible and unlimitable. ${ }^{18}$ At the same time in the 1830s and across the Atlantic, the American Supreme Court, in a series of cases usually associated with Chief Justice John Marshall, considered the status of the independent Indian tribes. The tribes were recognised by the federal common law as "domestic dependent nations" retaining a residual sovereignty with an inherent right to selfgovernment. ${ }^{19}$ Marshall's doctrine of tribal sovereignty was based upon the wider constitutional predicates the Americans had recently vindicated with blood and which his court was then articulating. This was an American vision of sovereignty as divided, confederative, popular and accountable; in a word justiciable. This was a form of constitutionalism which the British were unable to take. ${ }^{20}$ Britain in the early to mid nineteenth century was not wholly impervious to American constitutional practice for eventually it incorporated federalism into its imperial practice. But when it came in the 1850s and 1860s (in Australia, Canada, New Zealand and South Africa), that federalism was not conceived in the American style but in the pragmatism which is the hallmark of British constitutional practice. ${ }^{21}$ Marshall may have applied what was essentially, though not explicitly, a quasi-federative model to the Indian tribes, but that was one which was never even remotely a conceptual possibility for the tribes under British sovereignty. Locked in their view of unitary sovereignty, British officials regarded James Busby's Confederation of United Tribes $1835^{22}$ as a convenient way of dealing with the northern tribes en masse - as a potentially useful and pragmatic, albeit compromised, device ${ }^{23}$ - but,

18 See Henry Maine Ancient Law (Dent, London, 1861) 84, who termed it a postulate lying "at the threshold of the International Code, and it is also one which could not possibly have been subscribed to during the first centuries of modern European history".

19 Cherokee Nation $v$ State of Georgia (1831) 5 Peters 1; Worcester v State of Georgia (1832) 6 Peters 515; Mitchel $v$ United States (1835) 9 Peters 711.

20 On its ham-stringing effect on imperial practice see W Ross Johnston Sovereignty and Protection: A Study of British Jurisdictional Imperialism in the Late Nineteenth Century (Duke University Press, Durham (NC), 1973).

21 K Kendle Federal Britain A History (Routledge, London, 1997) 18-57.

22 "Declaration of Independence", signed by thirty five chiefs who "in the opinion of the Reverend W Williams" formed "a fair representation of the population of the Country" from North Cape to the River Thames" (28 October 1835) despatch and enclosure in Busby to Colonial Secretary (NSW) in CO 209/2: 95. (Copy received in Colonial Office 4 June 1836).

23 The Declaration contained an article against the Hokianga liquor laws passed by Busby's rival, the "Additional British Resident", James McDonnell, and that was regarded as a flaw: Bourke to Glenelg, 10 March 1836, CO 209/2:10. Busby protested that the Hokianga law could not have any effect as the Confederacy did not exist at the time of its purported enactment: Busby to Colonial Secretary (NSW), 16 March 1836 in CO 209/2: 210; Glenelg to Bourke, 26 August 1836 in CO 209/2: 20-21. 
unlike their officious Resident, they saw no constitutional possibilities or consequences in it. It was an indifference which had also marked British relations with the Six Nations Confederacy in the years after the Treaty of Paris 1763: Confederations of tribes were convenient conglomerations but were not endowed with any overarching, unified sovereignty.

The British inability at this time to conceive of sovereignty as limited, divided and confederative had less to do with imperial practice - although that had something to do with it - than the state of political conditions and thought within Britain itself. Here one must understand the importance of the representative principle in nineteenth century British political practice and thought. The mid-nineteenth century was the age of Parliamentary reform when the representative principle dominated Englishmen's conception of the constitution and proved itself elastic enough to achieve lasting reform. At this time the great Whig histories of Britain were being published, transmitting more than merely an account of British history. ${ }^{24}$ These were epic tales about the British constitution and the vindication and celebration of the representative principle. Parliament was thus cast as the triumphalist hero, the very foundation of this epic narrative and the answer to the "who" (held sovereignty) question, which for so long had obsessed British political history. Maine's (pre-)historism ${ }^{25}$ and Herbert Spencer's social Darwinism came to lubricate this tale, ${ }^{26}$ which saw the British Constitution, with Parliament ascendant, as the historically destined endpoint of centuries of constitutional life. The attachment to the representative principle runs arterially as the organising narrative theme of the influential Whig histories of the mid-nineteenth century. It was not merely influenced by, but was a direct outcome of the common law tradition and centuries of political experience. And we see recurring the two enduring features of common law method which we have already observed in ancient constitutionalism, namely the belief in the immortal continuity of the constitution and the present-minded use of the past by which the whole narrative momentum was determined by the eventual outcome: the triumph of Parliament and the representative principle.

24 JW Burrow A Liberal Descent: Victorian Historians and the English Past (Cambridge University Press, Cambridge, 1981). See also J Vernon "Narrating the Constitution: the Discourse of 'the Real' and the Fantasies of Nineteenth Century Constitutional History" in J Vernon Re-reading the Constitution: New Narratives in the Political History of England's Long Nineteenth Century (Cambridge University Press, Cambridge, 1996) 204, 206 suggesting that the histories of Macaulay, Stubbs and, later, Maitland "came to represent the founding texts of not just constitutional history, but the English historiographical tradition itself".

25 Stephen A Siegel "Historism in Late Nineteenth Century Constitutional Thought" [1990] Wisconsin Law Review 1431.

26 M Hawkins Social Darwinism in European and American Thought 1860-1945 (Cambridge University Press, Cambridge, 1997) 67-73. 
By the mid-nineteenth century, common law method and practice was positivising. Influenced by Bentham and, more dramatically, John Austin, a "science of law" was emerging and asserting its separateness from history. The common law changed from its classical form where it had been both a language of political discourse and way of thinking with its own internal logic. ${ }^{27}$ It was becoming the specialised language of a professional clerisy. Demands of external logic also came to be imposed upon the common law requirements of doctrinal coherence, uniformity and predictability. So from the beginning of the nineteenth century we see the formal doctrine of precedent emerging (and with it the makings of modern law reporting ${ }^{28}$ ), the law of contract developing quite dramatically ${ }^{29}$ and, in the academy law disengaging from history. Law became viewed as a positive command located in statute or case and the task of the lawyer essentially forensic - to retrieve that command.

This change was, of course, not merely a result of intellectual pressure for greater legal coherence. It was also, and more particularly, the juridical response to an industrialising and imperial Britain. The positivisation of common law method was a reform performed by the common law on itself; part of the implicit trade-off which ensured its domination of the ideological apparatus of Victorian Britain and Empire. The nineteenth century histories of Great Britain in glorifying the British constitution also glorified the common law itself. So successful was that achievement, so thorough and all-encompassing the belief in the historical continuity of the British constitution described in the great Whig histories, that the notion of sovereignty itself could also positivise: the sovereignty of the Crown-inParliament was put beyond any historical explanation. Detached from its historical foundation, for common lawyers the sovereignty of the Crown simply was there as though eternal. ${ }^{30}$

There has been no stronger example of that than the influential work of Albert Venn Dicey, the late Victorian jurist introduced to all law students at their first constitutional

GJ Postema Bentham and the Common Law Tradition (Clarendon Press, Oxford, 1986); M Lobban The Common Law and English Jurisprudence 1760-1850 (Clarendon Press, Oxford, 1991); D Lieberman The Province of Legislation Determined: Legal Theory in Eighteenth Century Britain (Cambridge University Press, Cambridge, 1989). Goldstein (ed) Precedent in Law (Clarendon Press, Oxford, 1987) 35-72.

29 Generally see P Atiyah The Rise and Fall of Freedom of Contract (Clarendon Press, Oxford, 1979) and J Gordley The Philosophical Origins of Modern Contract Doctrine (Clarendon Press, Oxford, 1991).

$30 \quad$ A Carty "English Constitutional Law from a Postmodernist Perspective" in P Fitzpatrick (ed) Dangerous Supplements: Resistance and Renewal in Jurisprudence (Pluto Press, London, 1991) 182, especially 199. 
law lecture (in my case by Professor Quentin-Baxter). Dicey distinguished legal from political sovereignty. Legal sovereignty was vested in the Crown, through its prerogative and in Parliament. The rules of legal sovereignty were for him immutable and fundamental common law principles. Dicey demonstrated how the historical validation of the sovereignty of the Crown-in-Parliament had disengaged from the legal explanation. This legal sovereignty was, and remains, the incontrovertible starting point for constitutional lawyers. Cast in an eternal present tense, the legal sovereignty of the Crown always is, like the common law itself, unscathed and untouchable by time, receding infinitely into the past and into the future; a force, no less, of secular redemption. ${ }^{31}$

For Dicey the two pillars of the British constitution were, first, the supremacy of the Crown-in-Parliament and, second, the rule of law. For him these two were like inseparable Siamese twins, each incapable of living without the other, and if one is to talk of Dicey as having a conception of sovereignty, it must be in the sense of these two aspects. ${ }^{32}$ However, the emphasis which he put upon Parliament's paramount status fitted in more obviously to the momentum of British political life which had carried the concern with the location of ultimate constitutional authority beyond 1745 and into the great Whig histories. Dicey was thus regarded as performing in legal doctrine what the Whig historians had accomplished historiographically, the monumentalising of the paramount sovereignty of the Crown-in-Parliament. That this subordination of the rule of law to the might of Parliament might not be so desirable did not occur to Dicey in 1885 who was a strong Whig; scornful of foreign constitutional practice (the French and the American especially), and holding a great belief in the institution of Parliament and the common law. Although there was no theoretical limit on the sovereign power, he believed there were implicit nonlegal limits. Of those, the most important were constitutional conventions and the fact that Members of Parliament were gentlemen and would, in his mind, behave accordingly. These, of course, were the days before the party system exerted a stranglehold over Parliament. That was an opinion he later came to doubt in the new century as anxiously he saw Home Rule and socialism engulfing his beloved constitution. ${ }^{33}$ However, in Dicey the supremacy of Parliament is able to become the foremost rule of constitutional law because of the endemic belief in the political principle of representation on which it rested. This belief in the ameliorative effect of the representative principle - the "political sovereignty"

31 AV Dicey Introduction to the Study of the Law of the Constitution (10 ed, Macmillan \& Co, London, 1962) 12-19.

32 Dicey, above n 31, 406-414.

33 John McEldowney "Dicey in Historical Perspective - A Review Essay" in P McAuslan and J McEldowney (eds) Law, Legitimacy and the Constitution (Sweet and Maxwell, London, 1985) 3961. 
of the electorate he termed it - enabled him to reconcile the apparent absolutism of our constitutional law with the democratic character of its exercise. His views were so influential precisely because this devotion to Parliamentary representation expressed a widespread belief and because it so perfectly matched political practice and the authorised versions of English political history.

I have given this very general description of British constitutional thought in the nineteenth century as a prelude to discussion of New Zealand. For the tradition of constitutional thought which has been dominant in this country through most of this century has been a continuation of the British one described by Dicey. ${ }^{34}$ Generations of New Zealand common lawyers have been reared in the Hobbesian tradition in which we are taught to view the sovereignty of the Crown as undivided and, the "manner and form" debate excepted, unlimitable. The accompanying sense of history which we are given of the New Zealand constitution is a more streamlined, condensed and vastly less turbulent version of the British one. The "better Britain" tale of our cultural history ${ }^{35}$ applies as strongly to our constitution, although it was a little later in emergence. It is the tale of an infant Crown colony moving through a rather pimple-free adolescence with responsible government to mature independent statehood with the adoption of the Statute of Westminster in 1947 and the final formality, the Constitution Act 1986. ${ }^{36}$ The development of our representative institutions becomes the yardstick of constitutional growth, and we are told that that growth, through childhood, teens and adulthood, has been a healthy and happy one. ${ }^{37}$ Nationhood, we are told, has its own unstoppable momentum. ${ }^{38}$

If one were to identify a period when this Whig constitutional consciousness took root in New Zealand one might associate it with the Liberal Government of 1891-1912. During this period a wide range of social legislation was passed. Historians have debated whether this was the beginning of the welfare state or not. ${ }^{39}$ Whatever it was, it certainly was a period from when the notion of the centralised unitary state as Leviathan could flourish.

34 See for example the editorial comments in Dicey, above n 31, 86, where New Zealand is identified as having "reproduced the purely Dicey doctrine in its entirety."

J Belich Making Peoples: A History of the New Zealanders From Polynesian Settlement to the End of the Nineteenth Century (Penguin Press, Auckland, 1996) especially 302. the Constitution (Brookers, Wellington, 1995) 368-404 ["Essays on the Constitution"]. on the Constitution above $\mathrm{n} 36,344-367$. 
The splendour of the tradition of constitutional thought which has dominated New Zealand common lawyers' conception of their constitution this century lies in its invisibility, its sheer humility. It is said, rather disingenuously, we have no "theory" of the constitution, yet we are led to believe our perfectly formed, clean-limbed constitution occurred osmotically. ${ }^{40}$ This observation is correct in the sense that our constitutional arrangements do not have a deliberative foundation (if we exclude the Treaty of Waitangi for a moment). But that is to state the rather obvious. However, for most of the twentieth century, constitutionally we have taken the Hobbesian position ${ }^{41}$ and that, in turn, has endorsed a wider political vision of the state as beneficent Leviathan. This absolutism has been the constitutional element in the philosophy of the welfare state. The observation that there is no theory of our constitution is also incorrect in as much as it might refer to the way in which we view the history of our constitutional experience, for here a theory - or blue-print or master narrative (whatever you may call it) - has been applied retrospectively: we have developed a state-centred (or Whig) history of our constitution which has so perfectly matched the drift of twentieth century political life in New Zealand as to be indiscernible. The sense of there being no history of our constitution other than this normal happy childhood and rather sedate adulthood, this Parliament-centred history, has been the historical consciousness of our constitution. We have had a theory as well as an historical consciousness of our constitution by the pretence of lacking them. ${ }^{42}$

Every week in some provincial or national paper, Pakeha New Zealanders reveal this disconnection from any sense of their historical selves. The "letters to the editor" pages are often full of Pakeha pillorying the Treaty of Waitangi. They ask why a document over 150 years old should have any worth today. They say it is better to scrap the Treaty and live in the here and now, in the conditions of a modern New Zealand unshackled to a distant, irrelevant past. This theme rings chorally through Pakeha vox pop on the Treaty. It is not necessarily a means of denying justice to Maori - although in some cases it can be - so much as an inability to see the past as haunting the political present. Pakeha politics, like

The Feel of Truth: Essays in New Zealand and Pacific History (Victoria University of Wellington, Wellington, 1969) 175.

40 PA Joseph Constitutional and Administrative Law in New Zealand (Law Book Company, Sydney, 1993) 107-112 ["Constitutional and Administrative Law in New Zealand"].

41 For instance GWR Palmer New Zealand's Constitution in Crisis - Reforming our Political System (McIndoe, Dunedin, 1992) decrying "the unfortunate influence of Thomas Hobbes" 42-44.

42 Constitutional and Administrative Law in New Zealand above n 40, 107: "New Zealand's progression from Crown colony to independent sovereign state has been regular, continuous and uneventful." 
the common law sovereignty of the Crown, seem to inhabit this eternal present where justice is distributive rather than historical. ${ }^{43}$

In the end I am making a rather simple point. It is that during the first 70 years of this century our sense of constitutional practice and history has matched our broader national political experience and vision: to repeat, the state as beneficent Leviathan. One of our greatest jurists, Sir John Salmond realised this vital connection between political practice and constitutional law (although as a "theoretical" jurist he avoided the historiographical element to which I have also been referring). He said: ${ }^{44}$

Constitutional law and practice react upon each other, each striving to assimilate the other to itself. The objective facts of state organization tend to mould legal theory into conformity with themselves. They seek expression and recognition through legislation, or through the lawcreating functions of the courts. Conversely, the accepted legal theory endeavours to realise itself in the facts.

Salmond took a much less static view than Dicey and his account of constitutional change presaged the important changes in public law taken by the common law decades later. He did not see the Hobbesian theory of sovereignty as logically pressing nor, inferentially, historically inevitable. Although purporting to provide principles of jurisprudence outside the common law paradigm, his reasoning showed how he was every inch the common lawyer. To him sovereignty was not subordinate to - that is, dominated by the "who" question - but encompassed by the rule of law; ${ }^{45}$ the classical common law position.

Like most in his time Salmond was also, however, a believer in the power of representation. Though he described in principle the incorporation of the sovereign power into the rule of law, there is no sign of him having modern notions of the justiciability of the Crown's conduct. His approach was one stressing the connection between constitutional practice and law and, at this time in national life, that practice and law put the Crown's relations with Maori in a special zone of the prerogative. Indeed it was Salmond who drafted the Native Land Act 1909 which effectively sealed Maori attempts to vindicate

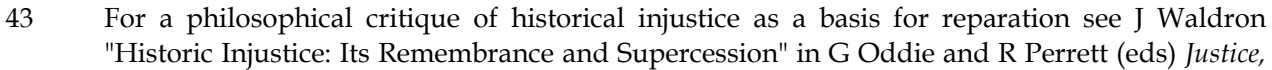
Ethics and New Zealand Society (Oxford University Press, Auckland, 1992) 139.

44 JW Salmond Jurisprudence or The Theory of the Law (Stevens and Haynes, London, 1902) 205.

45 Salmond, above n 44, Appendix II "The Theory of Sovereignty", 629. 
their aboriginal property rights in the courts. ${ }^{46}$ This legislation was passed partly ${ }^{47}$ to clarify conclusively ${ }^{48}$ the confusion arising from the Privy Council's advice in Nireaha Tamaki $v$ Baker ${ }^{49}$ and Wallis $v$ Solicitor-General. ${ }^{50}$ A large part of that had been achieved through the Land Titles Protection Act 1902, ${ }^{51}$ but, the 1909 Act finally and authoritatively silenced the possibility of Maori asserting aboriginal property rights against the Crown in the courts. ${ }^{52}$

In 1877, Chief Justice Prendergast had denied the Maori tribes any residual or even original sovereign status. ${ }^{53}$ This supported Crown sovereignty at a time when it was being challenged, for in the central North Island at least three tribes remained de facto "domestic nations". Prendergast CJ had described the Crown's relations with Maori as arising under a peculiar branch of the royal prerogative. This was a view which thirty years later Salmond

46 Salmond wrote a Memorandum for the Native Land Act 1909 which was published with the Act. He comments that the native title to customary land "cannot be asserted or enforced against the Crown by any form of legal proceeding." As against the Crown "it is not a legal title at all, but a mere moral claim under the Treaty of Waitangi to obtain a Crown grant" (at xi). See also s 84 (customary title not to avail against the Crown).

47 This Part of the Act was also passed to stifle pending claims to the Rotorua lakes and Ahuriri Lagoon (Napier): R Boast in Peter Spiller, Jeremy Finn and Richard Boast (eds) A New Zealand Legal History (Brookers, Wellington, 1995) 160; A Frame Salmond: Southern Jurist (VUW Press, Wellington, 1995) 112-119.

48 See comments of Attorney-General Sir J Findlay stating that in rendering the customary title unenforceable against the Crown, the Act's provisions were designed to clarify things once and for all: (1909) 148 NZPD, 1273. Also Frame, above n 47, 113.

49 Nireaha Tamaki v Baker (1900-01); [1840-1932] NZPCC 371.

$50 \quad$ Wallis $v$ Solicitor-General [1903] AC 173.

51 Refer comments of James Carroll, Native Minister, explaining the Bill in Committee stage, (1902) NZPD 120, 375.

52 Frame, above n 47, 114 notes Salmond considered it possible - and sufficient - that Maori could still obtain a declaratory judgment recognising their subsisting customary title or make an application to the Native Land Court.

53 Wi Parata $v$ Bishop of Wellington (1877) 3 NZ Jur (OS) 72. DV Williams warns against (whiggishly) demonizing Prendergast CJ saying that he was no more than applying the accepted position of his time: "Te Tiriti o Waitangi - Unique Relationship Between the Crown and Tangata Whenua?" in IH Kawharu (ed) Waitangi: Maori and Pakeha Perspectives (Oxford University Press, Auckland, 1990) 64. 
also endorsed ${ }^{54}$ - as did most of his legal brethren within the country. ${ }^{55}$ There was a broad legal and political consensus that relations with Maori were encompassed within that nonjusticiable area of the constitution comprising legal sovereignty. In this particular area, law and practice showed there was not what Salmond elsewhere called a "definite scheme of organised structure and operation", 56 except for that expressly laid down by the relevant statutes. Maori thus lacked any constitutional status or legal rights arising from their aboriginality - those dealings fell under the non-justiciable royal prerogative - except to the extent rights had been conferred by statute.

This part of our legal history has been looked at with increasing detail by scholars and Tribunal and I do not want to treat it other than in terms of the themes of this paper. But it can be observed that this phase was consistent with the constitutional climate and the prevalent notions of justiciability - with the dominance of a sovereign-centred constitutionalism in which the singular constitutional will of the Crown-as-Leviathan prevailed, or to put it another way the constitution seen essentially as a monologue. Relations with Maori were subsumed into the prerogative of the Crown which like all the powers of the legal sovereign remained beyond judicial reach. Maori were only accorded those rights expressly arising from the sovereign's will; that is, by statute. Maori's experience was that of the country at large, except they were crushed rather than cradled by Leviathan's gaze. There was no room or place for their voice in the historical and ongoing narrative of the New Zealand constitution.

\section{LIVING IN CLAIMS-TIME}

I have depicted this Age of Leviathan as emerging at the end of the nineteenth century from an incipient nationalism as well as an emergent cultural liberalism which stressed a humane and rational social order. With their linked themes of national destiny, egalitarianism, individualism and universalism, this nationalism and liberalism fed the more specific constitutional narrative. By the early 1960s the unified tradition was at its peak - as Sir John Salmond would have it, constitutional law and practice had tended towards one another. Maori had been substantially marginalised as a political force. This weakness left them more exposed to the ruthless logic of Leviathan, a vulnerability also experienced at this time by the aboriginal peoples of Canada and Australia. In all jurisdictions the detail differed but the core intention was the same: the Government

Frame, above n 47, 115 discussing Salmond's resistance to "judicialisation" of Maori claims which he contrasts with the "modern fashion" under the New Zealand Court of Appeal in the state enterprises cases and Waitangi Tribunal. 
regarded the retention by aboriginal peoples of special legal rights and status as discriminatory and proposed the removal of those rights. Faced with the loss of their remaining legal protection and status, aboriginal peoples were forced to assert their identity and sought legal elevation rather than elimination of their legal status. It was from Leviathan's final squeeze that what are often called "the years of anger" began.

During the 1970s, the claims of Maori began to take a new profile in political life - the great Land March, Bastion Point and the Raglan Golf Course are all episodes many of us will recall from this period in national life. The new Labour Government elected in 1972 reformed Maori affairs in numerous ways, of which in hindsight the most notable proved to be the establishment of the Waitangi Tribunal, although its jurisdiction did not then extend to historic claims.

Self-determination was the major overarching theme of these renewed claims: the right of native peoples to retain their cultural integrity whilst also enjoying full participation in the economic life of the nation-state. Rehabilitation of their land rights, with all the associated protective and restitutive elements, was invariably seen by native peoples themselves as part of this claim. However, in this new claims environment the Crown (in Canada most especially) insisted upon distinguishing issues of self-government (imperium) from land and related historical claims (dominium). In overall terms the axis of these claims, that of sovereignty or imperium and appropriation or dominium, was one thoroughly familiar to the history of western political discourse. ${ }^{57}$ Formulated in these terms aboriginal claims had accessibility, being articulated in the lingua parlata of the system from which they sought redress. However, the state's tactic was to separate sovereignty (imperium) from appropriation (dominium). That was a strategy mostly resisted by aboriginal people themselves as well as their radical supporters who bore an anti-state agenda of their own.

So it is that in these "years of anger" - the politics of claims-time - we have Maori claims pitched at two levels: imperium and dominium. It is hardly surprising that the Crown would try to confine those claims to the more specific level of dominium. In part this was because the issue of sovereignty was then, as now, inherently elusive and unresolvable. But also Maori, like the Canadian First Nations, were claiming that which Leviathan could not countenance: the existence within the state of alternative and untouchable sites of political authority. At this level the discourse of sovereignty involved the counterposition of an alternative sovereignty to that of the Crown. Essentially this was the politics of competing sovereignties, the politics not only of imitation but disputation and separation. This was nonetheless rhetorically attractive and politically flamboyant politics, attention-grabbing 
language and postures which required some response from the political system. The establishment of mechanisms to resolve Maori claims was part of that response.

So whilst Maori claims were being protested at this grand theatrical level of imperium, they were also being pursued by more moderate and practical Maori politicians at the more specific level of dominium, land claims. At this level Leviathan was not being challenged so much as petitioned, for the claims process was one of reaffirming the subject status of Maori, unlike the sovereignty claim. The mere making of the claim against the Crown supposed the capacity of the Crown to resolve it. In supposing the Crown's restorative powers, the claims process invested it with redemptive agency. This involved a subtle compromise of the sovereignty claim, one invisibly impairing aboriginal agency. The aboriginal peoples became supplicants before a Crown which was given the blame entirely for the colonialised condition of aboriginal peoples. Leviathan's authority over native people was thus confirmed rather than contested.

The dominium claims process also has other features which made it appealing to an awakened Leviathan: it fed specific claims into the political system with an implied expectation of eventual closure and exit. That is, it supposed that the difficulties that existed arose from the claim itself rather than the wider relationship between Crown and tribe. Once the claim became resolved it was - and still is - assumed that the relationship will no longer be problematic and that Maori will merge back into the population. ${ }^{58}$ Indeed this use of the claim as the fulcrum of the tribe's relationship with the Crown has become so compelling that tribes with whom a so-called full and final settlement has ostensibly been reached insist it is no more than a settlement for this generation. Maori are deeply suspicious of the "f" words, "full", "final" and "fixed", as they feel that resolution of the claim will be seen as severing the Treaty relationship. ${ }^{59}$ Maori politics thrives on this concept of the take (cause of action), but it frustrates Pakeha with their own cultural and political assumptions of closure and exit from the claim. Maori, of course, are seeing the claim as the lever for their management of their Treaty relationship with the Crown. This they know is an ongoing one. But that is not how most Pakeha see - or have been sold - the claims process. Their politicians have been giving them scant sense of the need to establish mechanisms for the ongoing relationship between Crown (the state) and Maori beyond the

More fully PG McHugh "Aboriginal Identity and Relations in North America and Australasia" in K Coates \& P G McHugh (eds) Kokiri Ngatahi - Living Relationships: The Treaty of Waitangi in the New Millenium (Victoria University Press, Wellington, 1998) 107, especially 114-116; A Fleras and R Maaka "Rethinking Claims-making as Maori Affairs Policy" 3 He Pukenga Korero (A Journal of Maori Studies) 43. Settling Tiriti Grievances" (1998) 8 Auck U LR 739, especially 756-765. 
claims process. In that regard the Maori position seems by far the less naive. Nonetheless, the implicit promise of closure and exit has been fundamental to the dominium claims process and whilst it may emphasise a result rather than a relationship, those results themselves (now they are beginning to happen in New Zealand and Canada) are altering significantly the landscape of aboriginal relations.

The sovereignty or imperium level of Maori claims was one where Leviathan's courts could hardly venture and where common law jurists tiptoed defensively. ${ }^{60}$ Whenever aboriginal sovereignty has been raised in the courts the judicial response has been sharp and immediately dismissive. ${ }^{61}$ In the non-legal sphere, however, imperium was, as I have mentioned, open to discussion. Whilst Maori and their radical supporters could posit an alternative subsisting sovereignty as absolute as that claimed by the Crown, ${ }^{62}$ others looked more closely instead at Leviathan's exercise of its own. Historians - Claudia Orange most famously - and the Waitangi Tribunal (the latter consciously removing any strict legal cap) led here. These sources produced critical accounts of Leviathan's treatment of Maori which nourished and gave political momentum to the dominium process. These were essentially historical reports; state-centred histories about Leviathan's exercise of imperium rather than the location of alternative sovereignties elsewhere in the islands. These histories were extremely present-minded descriptions of the past with guilt and Crown

60 Notably Professor FM Brookfield "Maori Rights and Two Radical Writers: Review and Response" [1990] NZLJ 406; Professor FM Brookfield "Kelsen, The Constitution and the Treaty" (1992) 15 NZULR 163; Professor FM Brookfield "The Treaty, the 1840 Revolution and Responsible Government" (1992) 5 Canterbury L Rev 59; Professor FM Brookfield "Parliament, the Treaty, and Freedom - Millennial Hopes and Speculations" in Essays on the Constitution above n 36, 41-60. See also the analysis in RA Sharp Justice and the Maori: Maori Claims in New Zealand Political Argument in the 1980s (Oxford University Press, Auckland, 1990) 266-281. Suggestions that Parliamentary sovereignty may not be so absolute in Treaty matters have been made by current members of the New Zealand bench (before appointment): S Elias (now Chief Justice) "The Treaty of Waitangi and the Separation of Powers in New Zealand" in BD Gray and RB McClintock (eds) Courts Policy: Checking the Balance (Brookers, Wellington, 1995) 206; Sir K Keith "The Roles of the Tribunal, the Courts and the Legislature" (1995) 25 VUWLR 129,139 calling it "a possible argument."

61 Berkett $v$ Tauranga District Court [1992] 3 NZLR 206, 207-208 (HC) per Fisher J; Harawira v R (5 October 1990) unreported, High Court, Whangarei Registry, AP 38/90 per Chilwell J noted in [1991] NZ Recent LR 149, 156. Walker v New South Wales (1994) 182 CLR 45, 48-49 per Mason CJ (citing Mabo v Queensland (No 2) (1992) 175 CLR 1; Coe v Commonwealth (1993) 118 ALR 193, 200); Coe v Commonwealth (1978) 18 ALR 592; Coe v Commonwealth (1979) 24 ALR 118. Also C Bell and M Asch "Challenging Assumptions: The Impact of Precedent in Aboriginal Rights Litigation" in M Asch (ed) Aboriginal and Treaty Rights in Canada Essays on Law, Equality and Respect for Difference (UBC Press, Vancouver, 1997) 39, 45.

62 See Sharp, above n 60, 256-265. Also Ranganui Walker "Maori Sovereignty, Colonial and Postcolonial Discourses" in Havemann (ed), above n 8, 108. 
response as their goal. In these "histories" the Treaty of Waitangi became a Lockean contract, the measure of legitimacy of Crown behaviour towards Maori: histories not of alternative sovereignties but the legitimacy in the exercise of the one - that held by the Crown. ${ }^{63}$

It was the courts, however, which played the pivotal role in taking things into the third phase, the politics of settlement. This was achieved through the two classic doctrinal preoccupations of the common law: the recognition of subsisting property rights and insistence upon procedural regularity.

First, courts in Australasia ${ }^{64}$ and Canada ${ }^{65}$ developed doctrine inconceivable a century before when aboriginal relations were regarded as part of the royal prerogative. The common law doctrine of aboriginal title became recognised judicially as a means of protecting extant aboriginal property rights. The doctrine was not, nor should it now be, seen as a literal reconstruction of the past. ${ }^{66}$ It is a common law depiction - the giving of contemporary legal consequence to certain facts of the past. It is today's legal, not yesterday's historical, truth. In Canada and Australia the doctrine has held enormous implications for the vast interior landmasses with their mineral riches. In Canada it has led to important land claims settlements in the north, although in Australia, Leviathan's response to its courts' recognition of the property rights of Aboriginal people has been vastly less respectful. New Zealand courts have also recognised the doctrine, although its scope remains uncertain. Aboriginal property rights are no longer a non-justiciable aspect of the Crown's prerogative - an incident of its unreviewable imperium as they were in the Age of Leviathan. They have become a question of dominium recognised and protected by the rule of law. This is a major change in judicial attitude, as some courts have noted, however much of the doctrine is dressed falsely as some historical truth.

Related to the recognition of aboriginal title has been the court's willingness to look at the relationship between aboriginal peoples and the Crown. This has been done by the Journal of History 117.

$64 \quad$ Mabo v State of Queensland (1992) 175 CLR 1; Wik Peoples $v$ State of Queensland (1996) 187 CLR 1; Te Weehi v Regional Fisheries Officer [1986] 1 NZLR 680 (CA); Te Runanga o Muriwhenua Inc v Attorney-General [1990] 2 NZLR 641 (CA); Te Runanganui o Te Ika Whenua Inc v Attorney-General [1994] 2 NZLR 20 (CA); Faulkner $v$ Tauranga District Council [1996] 1 NZLR 357 (CA). [1984] 2 SCR 335.

66 This has become the trend in Canada where claims are being brought for the invalidation of land titles on the basis of an historic infraction of the doctrine: Chippewas of Sarnia Band $v$ Attorney-General of Canada (30 April 1999) Ontario Superior Court, per Archie Campbell J. 
careful placing of the traditional sovereignty paradigm to one side as that is, of course, territory into which the courts will not venture. But despite this care there is nonetheless an aboriginal dimension permeating through the complex systems of public decisionmaking and administration. The Crown's relations with aboriginal peoples have been reconstructed by the common law through the transplantation of private law concepts into the public realm, and a growing insistence upon aboriginal participation and presence in public decision-making. The exercise of public power, notably a discretion arising from statute or prerogative, is now construed in terms of the Crown's fiduciary duties, obligations of good faith and partnership. The relationship that this produces is not necessarily one where there are any substantial limitations upon the power of Leviathan (except in Canada as a result of section 35 of the Charter). Rather this fiduciary relationship affects the manner in which Leviathan's officials exercise their constitutionally held discretionary power.

The emergence of a new judicial attitude towards the justiciability of aboriginal claims and their relations with the Crown can be seen as part of a broader trend in public law during the 1970s and 1980s. It is commonplace to see the recent history of public law in terms of the courts reasserting the equipoise of Dicey's two pillars of the common law constitution; the supremacy of Parliament and the rule of law. The rapid development of the common law of aboriginal rights should be seen as part of that trend in public law towards a greater willingness to render official conduct justiciable. No longer were the Crown's relations with Maori regarded as part of a special non-justiciable prerogative. In Treaty and matters of aboriginal rights the Court signalled that the Crown did not hold an open-ended discretion.

Therefore, the judgments of the New Zealand Court of Appeal in the Maori Council cases have been an important landmark in our national jurisprudence, a step in which the great contribution of Sir Robin Cooke (as he then was) should not go unnoticed. ${ }^{67}$ These cases have been fine examples of the modern common law working in the public sphere. The judgments did not confer substantive rights on Maori but required the Crown to enter into dialogue with Maori to agree on an outcome suitable to both. The judgments were concerned with voice and procedure, with legal principle guiding but not dictating the relationship and the accommodations to be reached.

The importance of these cases lay also in the way in which they have subtly defused the imperium debate. The Court spoke of tino rangatiratanga not in terms of the old 2 NZLR 129 (CA). 
Hobbesian paradigm, although it did note the rule of Parliamentary supremacy. ${ }^{68}$ Instead, relations with Maori were taken out of that vertical relation and put into a more horizontal zone. Necessarily that was a somewhat uneven or assymetrical one, but the Court conceived of Maori relations with the Crown in the language of personal relations: partnership, obligations of good faith, fiduciary-like duties. In other words, Crown - Maori relations were now seen as on-going and based on dialogue rather than the singularity of the Crown's one constitutional will. One commentator has described this judicial reconstruction of the relationship between Crown and Maori as establishing a common law ground of "constitutional" (as opposed to ordinary judicial) review. ${ }^{69}$

One finds a similar position in Canada where the federal government has recognised, since 1995, the inherent right to self-government as an aboriginal right under section 35 of the Charter. ${ }^{70}$ The inherent right is not packaged in the language of imperium, which itself is problematic in Canada with Quebec separatism. Instead self-government has been presented less combustibly as essentially a co-operative process to be played out in particular agreements with the various native groups. There is the public form of government in Nunavut, ${ }^{71}$ whilst other First Nations and bands have tended towards a municipal form. ${ }^{72}$

In New Zealand and Canada this rhetoric of new - or rather renewed - relations has been made effective by the conclusion of major claims settlements. However this is also generating a new climate - the politics of settlement - at which we will look now in terms of the two themes of constitutional and historiographical practice.

\section{SETTLEMENT-TIME}

Relations between Crown and Maori have entered, or rather are entering, a new phase which I have been calling "settlement-time". This is a new, more complex phase which is still very much at a formative stage of jurisprudential development, but which will grow

68 New Zealand Maori Council v Attorney-General [1987] 1 NZLR 641, 668 (CA).

69 P A Joseph "Constitutional Review Now" [1998] NZ Law Rev 85.

70 See PG McHugh "Aboriginal Identity and Relations in North America and Australasia" in K Coates \& P G McHugh (eds) Kokiri Ngatahi: Living Relationships (Victoria University Press, Wellington, 1998) 107, 128-130; A Fleras "Politicising Indigeneity: Ethno-Politics in White Settler Dominions" in Havemann (ed), above n 8, 187, 198-203.

71 Nunavut Act (Can), 40-41-42 Eliz II (1993), cap 28. See also D Purich The Inuit and Their Land: The Story of Nunavut (James Porimer and Co, Toronto, 1992).

72 Notably the Sechelt Indian Band Self-Government Act (Can), 33-34-35 Eliz II (1986), cap 27. See also JP Taylor and G Paget "Federal/Provincial Responsibility for the Sechelt" in DC Hawkes (ed) Aboriginal Peoples and Government Responsibility: Exploring Federal and Provincial Roles (Carleton University Press, Ottawa, 1989). 
in sophistication and complexity in the future. However, it is possible to identify, albeit in a very general and still rather nonspecific way, several emergent features of this new landscape.

In the politics of settlement one finds less recourse to the old sovereign relation. The reality may be that Parliament can legislate as it pleases and the practice of not legislating without Maori consent may be described in Diceyan terms as a constitutional convention. However, the political reality is that this convention has become formalised beyond the unwritten gentlemen's understanding of Dicey's description. The Maori voice is now more fully and formally incorporated into the legislative process. That trend in itself is part of the broader feature of the politics of settlement - a much greater awareness and meticulousness within government about procedure and ensuring the aboriginal voice. The political system - including its legal sphere - acknowledges now what previously it sought to suppress, namely the presence of dispersed sites of political authority within the existing constitutional framework. ${ }^{73}$ The concern of public law - not least in the field of aboriginal-Crown relations - is with the recognition and management of difference. Two years ago the federal government of Canada distributed a booklet to its departments setting out how to incorporate the Crown's fiduciary duties into governmental procedure. The federal government noted the lack of clarity surrounding this fiduciary duty but saw it mainly (and I think rightly) in procedural terms. Today, Government officials overlook or dismiss the aboriginal element at their peril.

The politics of settlement have also produced a more complex, diverse theatre. No longer is there the simple bipartite claims-based relation of Crown and Maori. In settlement-time national politics begins to experience the vitality and diversity of aboriginal politics. One notable expression of that has been native groups bringing their internal disputes and political wrangling before the courts. These cases often concern leadership and decision-making within the First Nation, tribe or band. The other type of case, yet really to emerge in New Zealand, concerns the rights and (more usually) liability of the aboriginal group to third parties in contract and tort. As they manage their growing asset-base and enter into relations with third parties, disputatiousness is only to be expected. It is a natural enough feature of politics everywhere. As the profile of such litigation grows - as inevitably it will - we may expect to see an emergent indigenisation of the common law as it responds to and absorbs elements of native custom in particular areas such as the law of obligations.

There is an issue here about the extent to which the courts should be drawn into matters of internal aboriginal politics. Necessarily they will have to adjudicate where third 
party interests are involved - contracts of employment are an example in the Canadian caselaw. ${ }^{74}$ However, should the courts resolve issues of disputed leadership or decisionmaking processes arising entirely within aboriginal society? In the United States the doctrine of residual tribal sovereignty has enabled courts largely to avoid issues of leadership selection, mandate and, to some extent, of status. ${ }^{75}$ But we know that no such doctrine applies in the common law jurisdictions of Australasia and Canada. There has been, for example, an enormous growth in litigation in Canada over band council elections. The Canadian courts ${ }^{76}$ have been using principles of administrative law in these and other matters of internal aboriginal processes. However, there is an artificiality about this which, although it may lead to workable results, is not especially satisfying in principle. In New Zealand how does the potential for such judicial intervention square with tino_rangatiratanga? Maori have long been used to the Maori Land Court having something of a role in their internal politics and deliberations but that has mainly related to the administration of a specific and rather depleted asset, Maori freehold land. Such settlements as those affecting Tainui, Ngai Tahu and Whakaue put such issues in an entirely different ball park.

In settlement-time, other players like large national and transnational corporations have also entered the field. These too have begun making deals with native peoples. Many of these companies are adopting specific policies and cultivating their relations with aboriginal peoples through instruments such as joint ventures, employment policies and revenue-sharing agreements: a scenario unthinkable a generation ago. And apparently new players - new native groups claiming ethnic identity - also enter the picture. Existing aboriginal polities (tribe, sub-tribe or band) sometimes divide to produce new tribes, subtribes or bands. This in turn raises issues about the nature of political change and reorganisation within aboriginal culture and national politics at large: for instance, urban aboriginals have been identifying themselves ethnically through their patterns of residence and association rather than tribal affiliation or other historically established forms of status. ${ }^{77}$ The status of these people within aboriginal politics is unclear and controversial.

Chadee v Norway House First Nation [1996] 10 WWR 335 (Man CA); Ashenhurst v Chinki Band (1995) 16 CCEL (2d) 53; Celtic Shipyards (1988) Ltd v Marine Workers' and Boilermakers' Industrial Union, Local 1 [1994] 3 CNLR 41 (BCLRB); Noel v Little Shuswap Indian Band (25 April 1994), Doc Kamloops 20181 (BCSC).

76 For instance: Sheard v Chippewas of Rama First Nation Band Council (1996) 42 Admin LR (2d) 265, 114 FTR 44; Ermineskin v Ermineskin Band Council (1995) 96 FTR 181; Yellowquill v Assiniboine/Myran (1995) 93 FTR 310. claiming access to a provincial "Casino First Nations Fund"). 
As the dispute in the courts about the allocation of the Maori fisheries income has been demonstrating, the mechanisms of the national political system will be co-opted in such situations. If in claims-time it was possible to speak simplistically and singularly of an "aboriginal voice", in settlement-time there is a dynamic plurality not always singing from the same hymn sheet.

As aboriginal litigation continues one begins to note a curious trend at least in litigation against the Crown. For the most part there is a distinct sense today that the landmark judgments on aboriginal rights have been given and that most judicial activity is regarded as filling in the detail. That detail is not as responsive to aboriginal peoples as might have been hoped, indeed it is showing a marked unresponsiveness. The judgments of the Supreme Court of Canada in the Van der Peet ${ }^{78}$ and Delgamuukw ${ }^{79}$ cases highlight this emergent judicial reluctance to extend common law aboriginal title rights and to keep those as "way of life" rights, as a circumscribed dominium kept well away from the imperium zone. ${ }^{80}$ These cases have limited the aboriginal title to its traditional elements, particularly aboriginal servitudes and have not included self-determination within the scope of section 35 of the Charter. The property right is preserved but denied a dynamic element. ${ }^{81}$ The judgment of the majority of the Court of Appeal in McRitchie ${ }^{82}$ (the trout fishing case) is fully consistent with that trend, ${ }^{83}$ however much we heed the majority's protestation that the judgment is limited to the particular facts.

Alongside the increasing conservatism in caselaw doctrine is a growing judicial undercurrent that the questions coming before the courts arising from the Crown's new forms of agreement with aboriginal peoples are less amenable to judicial resolution. In New Zealand this is justified through the rhetoric of "partnership" with its underlying contractualist approach, seeing the area of relations encompassed by (potential) negotiation as a "political zone" best left to the parties for dialogue and agreement amongst themselves. This is a position with which many Maori concur. ${ }^{84}$ So we reach the paradox

$78 \quad$ R v Van der Peet (1996) 137 DLR (4th) 289 (SCC).

79 Delgamuukw v British Columbia (1997) 153 DLR (4th) 193 (SCC).

80 M Asch "From Calder to Van Der Peet, Aboriginal Rights and Canadian Law 1973 - 1996" in Havemann (ed), above n 8, 428.

81 For instance L Rotman "Creating a Still-life Out of Dynamic Objects: Rights Reductionism at the Supreme Court of Canada" (1997) 36 Alberta Law Review 1.

82 McRitchie v Taranaki Fish and Game Council [1999] 2 NZLR 139 (CA).

83 See the excellent critique by Richard Ogden "Inchoate Aboriginal Rights" [1999] NZLJ 183.

84 M Turei "Litigation is an Evil" (1998) 8 Auck U LR 900; A Kawharu "Urban Iwi: The New Tribes of Maoridom?" (1996) 8 Auck U LR 209, 211. 
where these relations between Crown and Maori seem to be re-acquiring a measure of non-justiciability.

This process - the jurisprudence of settlement - has been called the "commodification" of Maori claims. ${ }^{85}$ Certainly some such outcome was inevitable if the negotiation required by the courts was to be conducted in good faith and sincerity (as undoubtedly appears to be the case). Crown and Maori would have to agree to something and that must result in the quantification of the Treaty rights alleged to have been violated. The growing sophistication and complexity of this jurisprudence signals also that the compass of the rule of law is being redrawn so as to include Maori relations with the Crown and amongst themselves. This has been accomplished by the discarding of the old Diceyan fixation with the "who" question concerning the location of paramount imperium. Instead the courts have become more concerned - as they have in other spheres of public life - with the manner of exercise of public power as it reaches into Maori life. The boundaries of the rule of law have been redrawn and the sovereignty of the state reasserted, sovereignty in the sense of the integrity of a system governed by law. Beneath this is the realisation that public authority is exercised within a set of political relationships reached by law. This spreading notion of justiciability, however unresolved and indeterminate its reach may at present be, has not been confined to Maori issues, and highlights this returning re-equilibrium in public law between Dicey's two pillars of the constitution. This is the equipoise lost during Leviathan's century.

And how do we view the past of our constitution in the new landscape of settlementtime? Well the certainties and the comforts (for those who could take them) of the Age of Leviathan are truly gone. If claims-time made us review the Crown's exercise of its imperium over aboriginal peoples, the theme of settlement-time seems to be the rediscovery of dispersed political authority. The fiction fostered by the nationalism, liberalism and protectionism of the Age of Leviathan has dissolved and constitutional practice has become more concerned with the management rather than supression of difference. The reform of the New Zealand electoral system into Mixed Member Proportional Representation (MMP) is a dramatic expression of some such realisation and constitutional provision for multiple voices within the political system. MMP can be seen as an attempt, although perhaps no more than a partial one, to rehabilitate the representative principle as the mechanism for constitutional containment. 1990) at 12-23; Paul Havemann "Indigenous Rights in the Political Jurisprudence of Australia, Canada and New Zealand: Parallel Chronologies" in Havemann (ed), above n 8, 22, 23-24; A Cheater and N Hopa "Modelling the Commoditisation of Maori Land: Incorporating Identities" in Havemann (ed), above n 8. 
And how does this diverse polity with its "strange multiplicity" see itself historically? New Zealand historians like Jamie Belich ${ }^{86}$, Judith Binney ${ }^{87}$ and Angela Ballara ${ }^{88}$ are telling us of a past in which there were alternative mutually-acknowledging and dynamic sites of political authority. New Zealand constitutional historians - that rare breed - will, I expect, rediscover our political history before the Age of Leviathan. This was a period of 30 to 40 years, a good generation or so of constitutional experience, when governance within New Zealand was seen more in federative terms ${ }^{89}$ than the metropolitan absolutism of the Colonial Office. In the first half-century after British sovereignty, New Zealand experienced not only the quasi-diplomatic highly dynamic politics of tribalism, but also provincialism ${ }^{90}$ and the country also debated imperial federation. ${ }^{91}$ Those histories of dispersed and not necessarily antagonistic sovereignties may have been disjointed and momentary but they were not false starts in the inevitable progress towards the centralising Age of Leviathan. At the time they were major issues in political life and those who participated themselves felt no sense of historical inevitability any less or more than that which we feel today. If today we lack a sense of the place such matters held on our ancestors' political agenda it is only because we have since been swamped by the history of Leviathan. But at least we are losing that awe for the majesty of Leviathan that was transmitted to this "Better Britain" in the South Seas and which gripped the constitutional imagination of earlier generations.

So as New Zealand encounters the politics of settlement there are new demands upon its public law and the sense we have of our constitutional past. We know today that the constitution is not the place of tranquility and harmony we might once have been led to believe yet, like the Argonauts' ship, it is still the same constitution. Today a constitution is

James Belich Making Peoples: A History of the New Zealanders From Polnesian Settlement to the End of the Nineteenth Century (Penguin Books, Auckland, 1996).

87 Judith Binney Redemption Songs: A Life of Te Kooti Arikirangi Te Turuki (Auckland University Press and Bridget Williams Books, Auckland, 1995).

88 Angela Ballara Iwi: The Dynamics of Maori Tribal Organisation from c 1769 to c 1945 (VUW Press, Wellington, 1998).

89 "Law, Sovereignty and History" above n 6, 487-488.

90 The leading text remains WP Morrell The Provincial System in New Zealand 1852-76 (2 ed, Whitcombe and Tombs Ltd, Wellington, 1964).

91 Particularly during a three month flurry in 1899 although the issue had simmered from the Federation Conference in 1890: K Sinclair "Why New Zealanders are not Australians: New Zealand and the Australian Federation Movement, 1881-1901" in Sinclair (ed) Tasman Relations: New Zealand and Australia, 1788 - 1988 (Auckland University Press, Auckland, 1988) 102. 
about the navigation of difference and that also is becoming the means by which we understand it historically. The rule of Parliamentary supremacy remains, but it does not wrap us in a warm cosy blanket of reassurance. It simply tells us where the ultimate lawmaking authority in our constitutional system is located. Our political culture has realised that national pluralism cannot be accommodated wholly through the representative principle and that, perhaps, is the single most important change in our constitutional consciousness this century. That consciousness has moved from a denial of diversity through realisation to living with it. And if that means our constitutional culture seems more turbulent then that is more likely a sign of constitutional maturity than a nostalgic hearkening back to the complacent fictions of an harmonious and homogenous polity. Those fed the constitutional requirements of another time and only a segment of the nation.

It is clear that the position of the aboriginal peoples of New Zealand in the common law constitution is plainly not the same as a century ago. Yet, to recall the Argonauts' metaphor, it is still demonstrably the same common law; the common law then as now caught up in its turbulent present, improvising with doctrine and navigating through its past by the needs of the present. Imperfect perhaps and its work always unfinished, but a sincere, hardworking and vital tradition which we celebrate in this centenary of the law teaching in Wellington, New Zealand's capital city. 
